\title{
THE DARKER SIDE OF INNOVATION
}

Frank Land ${ }^{1}$, Helga Drummond ${ }^{2}$, Philip Vos Fellman ${ }^{3}$ (and Roberto Rodriguez), Steve Furnell ${ }^{4}$, and Prodromos Tsiavos ${ }^{5}$

${ }^{I}$ Department of Information Systems, London School of Economics, UK; ${ }^{2}$ Department of Decision Sciences, Liverpool University, UK; ${ }^{3}$ School of Management, University of Southern New Hampshire, USA; ${ }^{4}$ Plymouth University, UK; ${ }^{5}$ Department of Information Systems, London School of Economics, UK

Key Words Cybercrime, Open-Source, Peer-to-Peer, Malfeasance, Fraud, Criminal Innovation, Espionage

Abstract: Innovation is widely regarded as one of the crucial capabilities if an enterprise is to be successful and to sustain its success (Kay, 1993). John Simmons, Chief Comptroller of J. Lyons and 'father' of the LEO project said:

Innovation is the lifeblood of successful business management. Without innovation the most successful business will ultimately become of no more value than the once fabulous but now worked-out gold mine. (Simmons, 1962)

However there is an asymmetry in most of the discussion of the field. Innovation is primarily discussed as a force for progress even if, as in the GM debate, the direction of progress is sometimes challenged. In general innovation is regarded as something which benefits society a large.

There is much less discussion, except in the specialist literature, of cybercrime (Furnell, 2001), of the way innovation is a part of the apparatus of fraudsters, criminals, tyrants and the mischievous. Innovation, too, is used to challenge the established system of business values and the powers of the business elite.

The intention is for the panel to debate some of the issues. Panellists are each specialists in some area relevant to the theme. Professor Helga Drummond of Liverpool University (see Drummond, 2003), who has recently written about the Baring Bank, Nick Leeson affair, considers that as businesses systems evolve and change cracks appear in the system, and opportunistic innovators take advantage of these for their own, often nefarious purposes. 
Dr Steven Furnell, Plymouth University and Research Co-ordinator of the Network Research Group theme is the ongoing battle between two classes of innovators:

1. Those who attempt to break down the security and integrity of systems partly for mischievous reasons such as some hackers, some to weaken competition by disabling the network, some to wreak vengeance for some slight. Their chosen weapons are viruses worms and spam.

2. Those who try to build defences against the first group. These include not only technical specialists such as those working in the field of encryption, but lawyers drafting new types of regulation.

The third panellist is Prod Tsiavios a Ph.D student at the London School of Economics. He has studied the peer-to-peer and open source movements and his theme is the evolution of approaches which attempt to get around conventional methods of protecting markets via intellectual property laws and regulations.

Finally Professor Phillip Vos Fellman from Southern New Hampshire University and Dr Roberto Rodriguez will together reflect on the dark side of the internet from the perspective of investigators studying the impact of dark innovation.

\section{References}

Drummond, H, (2003), Did Nick Leeson have an accomplice? The role of information technology in the collapse of Barings Bank, Journal of Information Technology, Vol. 18, No. 2, pp. 93-101, June

Furnell, S., (2001), Cybercrime: Vandalizing the Information Society, Addison-Wesley, Boston.

Kay, J., (1993), Foundations of Corporate Success: How business strategies add value, Oxford University Press, Oxford.

Simmonds, J.R.M., (1962), 'LEO and the Managers, Macdonald, London. 